\title{
Pengaruh Defisit Pendanaan Internal Terhadap Struktur Modal
}

\author{
Andik Susanto $^{1}$, Novy Rachma Herawati ${ }^{2}$ \\ ${ }^{1}$ Program Studi Manajemen, Universitas Merdeka Madiun, Jl. Serayu No.79, Madiun, 63133 \\ E-mail: andiksusanto@unmer-madiun.ac.id \\ ${ }^{2}$ Program Studi Manajemen, Universitas Merdeka Madiun, Jl. Serayu No.79, Madiun, 63133 \\ E-mail: novy@unmer-madiun.ac.id
}

\begin{abstract}
Companies manage its capital structure in order to provide benefits to the company so as to encourage management to manage the capital structure so that the composition of debt or equity can be adjusted with the aim of management in selecting the composition. This research focuses on the pecking order theory by taking a sample of 33 property, real estate, and building construction companies listed on the Indonesia Stock Exchange with the observation year 2015 to 2017. The purpose of this study is to see if there is consistency of research, as well as the previous studies to answer the research gap of extended pecking order theory model to see the effects of internal funding deficit and the debt ratio to the addition of forming internal funding deficit (dividends payment, additional working capital, investment and net cash flow) for additional debt ratio that can be used as a factor affecting changes in capital structure. The final results in this study support the hypothesis that the entire internal funding deficit has a positive effect on additional debt ratio. Dividend payments, additional working capital, net cash flow, and investment have a positive effect. So the company can be said to support the pecking order theory.
\end{abstract}

Keywords-: capital structure; pecking order theory; internal funding deficit; dividend payments; additional working capital.

\section{PENDAHULUAN}

Perusahaan dalam menjalankan operasionalnya memerlukan adanya pendanaan. Pendanaan ini diperlukan oleh perusahaan tidak hanya untuk menjalankan operasional rutin tetapi juga bertujuan untuk menambah pangsa pasar atau bahkan untuk mendukung strategi perusahaan demi menjaga keberlangsungan perusahaan. Pendanaan ini dapat dilakukan baik dengan menambah modal sendiri atau bahkan menambah hutang dari pihak lain. Kebutuhan akan pendanaan yang diperlukan oleh perusahaan tersebut akan mempengaruhi komposisi struktur permodalan atau lebih dikenal dengan istilah Capital Structure. Struktur modal merupakan komposisi permodalan perusahaan yang terdiri dari hutang baik hutang jangka pendek atau jangka panjang serta saham yaitu saham preferen ataupun saham biasa sedangkan struktur keuangan merupakan komposisi perimbangan antara total hutang dengan total modal yang dimili sendiri (Sartono, 2010: 225).

Banyak teori yang berkaitan dengan struktur modal seperti teori pendekatan tradisional, Modigliani dan Miller, teori trade-off, teori pecking order ataupun teori lainnya seperti keagenan. Teori- teori tersebut pada akhirnya membuat pandangan yang berbeda di kalangan manajemen. Dalam teori pendekatan tradisional contohnya, manajemen akan melakukan penambahan dana dari hutang agar nilai perusahaan mengalami perubahan. Berbeda dengan teori pecking order yang lebih mengutamakan adanya urutan atau pecking order untuk melakukan penambahan pendanaan jika perusahaan mengalami defisit atau dana yang dimilikinya berkurang.

Di Indonesia masih sedikit penelitian yang menguji pecking order theory dengan menggunakan sampel perusahaan perusahaan yang terdaftar di Bursa Efek Indonesia dan memakai variabel defisit pendanaan internal. Adapun penelitian yang sudah ada dengan menggunakan variabel defisit pendanaan memberikan kesimpulan yang berbeda sehingga masih terdapat research gap. Oleh karena itu penelitian ini ingin memfokuskan pada pengujian pecking order theory dan mengkaitkannya dengan perubahan struktur modal yaitu perubahan rasio hutang terhadap modal dan pada akhirnya penelitian ini berupaya untuk melihat hubungan yang signifikan dari perubahan struktur modal yang diwakili oleh kenaikan rasio hutang dengan defisit pendanaan internal sehingga dapat dijadikan bukti pendukung dari pecking order theory. Perusahaan yang dijadikan bahan penelitian adalah perusahaan yang memang memerlukan pendanaan yang sangat besar yaitu perusahaan bidang real estate, property, dan konstruksi yang pendanaannya dihabiskan untuk investasi pada aset tetap atau modal kerja.

\section{RUMUSAN PERMASALAHAN}

Perusahaan dalam membuat kebijakan keuangannya akan dipengaruhi oleh banyak faktor. Perubahan kebijakan keuangan tersebut akan mempengaruhi struktur permodalan perusahaan. Penelitian ini lebih memfokuskan pada pengujian pecking order dan berupaya membuktikan dengan melihat faktor - faktor yang mempengaruhi perubahan struktur modal yang terwakili oleh perubahan rasio hutang. Penelitian ini juga diharapkan akan menambah bukti empiris mengingat masih sedikit penelitian 
Website : http://ekomaks.unmermadiun.ac.id/index.php/ekomaks

pecking order theory di Indonesia dengan menggunakan variabel defisit pendanaan internal dan menghubungkannya dengan penambahan rasio hutang.

\section{A. Pertanyaan Penelitian}

Dalam pecking order theory extended, defisit pendanaan internal dijabarkan lebih lanjut menjadi 4 variabel yaitu pembayaran dividen, investasi, penambahan modal kerja, dan aliran kas bersih. Dari penjabaran defisit pendaaan internal tersebut maka didapat pertanyaan:

1. Apakah defisit pendanaan internal berpengaruh terhadap perubahan struktur keuangan pada perusahaan property, real estate, dan konstruksi yang terdaftar di Bursa Efek Indonesia?

2. Apakah pembayaran dividen berpengaruh terhadap perubahan struktur keuangan pada perusahaan property, real estate, dan konstruksi yang terdaftar di Bursa Efek Indonesia?

3. Apakah aliran penambahan modal kerja berpengaruh terhadap perubahan struktur keuangan pada perusahaan property, real estate, dan konstruksi yang terdaftar di Bursa Efek Indonesia?

4. Apakah investasi berpengaruh terhadap perubahan struktur keuangan pada perusahaan property, real estate, dan konstruksi yang terdaftar di Bursa Efek Indonesia?

5. Apakah aliran kas bersih kerja berpengaruh terhadap perubahan struktur keuangan pada perusahaan property, real estate, dan konstruksi yang terdaftar di Bursa Efek Indonesia?

\section{B. Tujuan Penelitian}

Penelitian ini memiliki tujuan sesuai rumusan masalah yang telah dikemukakan sebelumnya yaitu:

1. Untuk menguji pengaruh defisit pendanaan internal berpengaruh terhadap perubahan struktur keuangan pada perusahaan property, real estate, dan konstruksi yang terdaftar di Bursa Efek Indonesia?

2. Untuk menguji pengaruh pembayaran dividen berpengaruh terhadap perubahan struktur keuangan pada perusahaan property, real estate, dan konstruksi yang terdaftar di Bursa Efek Indonesia?

3. Untuk menguji pengaruh aliran penambahan modal kerja berpengaruh terhadap perubahan struktur keuangan pada perusahaan property, real estate, dan konstruksi yang terdaftar di Bursa Efek Indonesia?

4. Untuk menguji pengaruh investasi berpengaruh terhadap perubahan struktur keuangan pada perusahaan property, real estate, dan konstruksi yang terdaftar di Bursa Efek Indonesia?

5. Untuk menguji pengaruh aliran kas bersih berpengaruh terhadap perubahan struktur keuangan pada perusahaan property, real estate, dan konstruksi yang terdaftar di Bursa Efek Indonesia?

\section{Manfaat Penelitian}

Penelitian ini diharapkan dapat memberikan manfaat bagi manajemen khususnya manajemen di perusahaan property, real estate dan konstruksi yang terdaftar di Bursa Efek Indonesia untuk dijadikan bahan pertimbangan mengenai faktor- faktor yang mempengaruhi adanya defisit pendanaan internal yang pada akhirnya akan mempengaruhi perubahan struktur modal yaitu adanya perubahan rasio total hutang terhadap total aset. Bagi akademisi, penelitian ini dapat menjadi tambahan research gap di Indonesia mengingat masih sedikitnya penelitian pecking order theory dengan mengguanakn variabel defisit pendanaan internal dan sekaligus bukti empiris sebagai pendukung pecking order theory pada perusahaan property, real estate, dan konstruksi yang terdaftar di Bursa Efek Indonesia.

\section{Ruang Lingkup Penelitian}

Batasan penelitian ini adalah hanya meneliti perusahaan yang terdaftar di Bursa Efek Indonesia yaitu sub sektor property, real estate, dan konstruksi. Adapun periode pengamatan adalah 3 tahun yaitu tahun 2015, 2016, dan 2017. Penelitian ini lebih memfokuskan pada pembentuk defisit pendanaan internal yaitu: pembayaran dividen, penambahan modal kerja, investasi dan aliran kas bersih. Sedangkan untuk variabel dependennya adalah rasio hutang atau penambahan debt ratio.

\section{III.TINJAUAN PUSTAKA}

\section{A. Struktur Modal}

Struktur modal merupakan komposisi perimbangan mengenai jumlah hutang jangka pendek, hutang jangka panjang, saham preferen dan saham biasa, sedangkan struktur keuangan merupakan komposisi perimbangan antara total hutang dengan total modal yang dimiliki sendiri (Sartono, 2010: 225). Struktur keuangan serta perubahan strukur modal dapat dilihat dengan mudah dengan melihat aktiva yang terwakili oleh total aktiva dan pasiva yang terwakili oleh total hutang dan total modal (Weston dan Copeland, 2010: 19)

Beberapa manajemen menilai perubahan struktur permodalan akan mempengaruhi nilai perusahaan. Seperti manajemen yang menganut teori tradisional bahwa perusahaan yang memiliki hutang pada batas tertentu akan menambah nilai perusahaan dan nilai tersebut akan tercermin dalam harga saham. Perubahan struktur permodalan juga akan memberikan signal jika dikaitkan 
Website : http://ekomaks.unmermadiun.ac.id/index.php/ekomaks

dengan teori signaling bahwa manajemen ingin berupaya menambah pangsa pasar atau memperluas pasar dengan adanya penambahan pendanaan dengan melihat adanya perubahan hutang atau perubahan modal sendiri.

Pecking order theory lebih menekankan pada karakter manajemen dalam mencari dana ketika perusahaan mengalami kekurangan dana atau istilah lainnya adalah adanya defisit pendanaan internal. Pecking order theory tidak menekankan pada perubahan nilai perusahaan tetapi dampak penambahan dana akan mempengaruhi struktur modal dan bagi kalangan tertentu akan perubahan struktur modal dapat mempengaruhi nilai perusahaan. Dalam pecking order theory, perusahaan akan menggunakan dana internal terlebih dahulu untuk kegiatan operasional dan ketika dana internal yang diambil dari laba ditahan mengalami defisit maka perusahaan akan melakukan cara dengan menambah hutang terlebih dahulu dan kemudian menambah saham yang beredar. Hutang menjadi pilihan kedua setelah laba ditahan mengalami defisit dikarenakan biaya dari hutang sangat mudah dianalisa daripada ketika perusahan harus menambah jumlah saham yang beredar yang nantinya investor akan meminta adanya pengembalian dari investasi yang semakin tahun akan semakin naik yaitu tercermin dari kenaikan pembayaran dividen per lembar sahamnya. Manajemen juga beranggapan bahwa kegiatan untuk menambah jumah saham memerlukan biaya lebih besar jika dibandingkan dengan penambahan hutang.

Teori struktur modal secara umum menjelaskan bahwa kebijakan perubahan permodalan memiliki dampak pada perubahan nilai atau tidak memberikan dampak pada perubahan nilai perusahaan. Struktur modal dapat dikatakan optimal jika pada komposisi tertentu dan tingkat risiko tertentu memberikan nilai yang optimal pada perusahaan. Banyak teori yang mendukung adanya perubahan struktur modal mempengaruhi nilai, tetapi belum ada yang menjelaskan secara rinci berapa tingkat komposisi yang ideal antara hutang dan modal (Hanafi, 2012: 297).

Adapun teori yang membahas mengenai struktur modal antara lain Pendekatan Tradisional, Teori Modigliani dan Miller, Teori Trade-Off, Teori Keagenan, Teori Pecking Order dan sebagainya. Dalam pendekatan tradisional, manajemen berganggapan bahwa adanya pengaruh struktu modal dengan nilai perusahaan sehingga manajemen berupaya untuk merubah komposisi struktu permodalan dan mengharapkan akan mempengaruhi nilai pada perusahaan. Berbeda denga pendekatan tradisional, teori Modigliani dan Miller berpendapat bahwa struktur permodalan tidak akan mempengaruhi nilai perusahaan, asumsi ini didasarkan bahwa tidak ada faktor pajak dalam perusahaan sehingga dua perusahaan yang memiliki komposisi permodalan yang berbeda maka nilai kedua perusahaan tersebut sama.

Tetapi teori Modigliani dan Miller ini diperbaiki dengan memasukkan pajak sebagai biaya tambahan dan pada akhirnya memiliki kesimpulan yang sama bahwa komposisi struktur permodalan akan merubah nilai perusahaan. Teori trade - off berupaya mendukung teori Modigliani dan Miller dengan memasukkan faktor biaya kebangkrutan dan biaya keagenan dari konsekuensi kenaikan hutang yaitu adanya kenaikan risiko kebangkrutan dan kenaikan biaya keagenan ketika perusahan berupaya menaikkan rasio hutangnya.

\section{B. Pecking Order Theory}

Pecking order theory menjelaskan urutan jenis pendanaan yang akan diambil oleh perusahaan ketika perusahaan membutuhkan adanya tambahan dana untuk kegiatan atau strategi bisnisnya. Adapun urutan skenario atau urutan pecking order adalah:

1. Dana internal akan digunakan terlebih dahulu yaitu dengan menggunakan dana dari laba ditaha

2. Perusahaan akan menggunakan dana eksternal jika dana internal kurang mencukupi. Adapun urutan untuk dana eksternal adalah

a. Mengeluarkan surat berharga yaitu obligasi

b. Surat berharga campuran seperti obligasi konvertibel

c. Terakhir adalah mengeluarkan saham jika dari penerbitan obligasi masih belum mencukupi untuk pendanaan.

Pecking order theory tidak dapat menjelaskan perubahan nilai perusahaan atas perubahan komposisi permodalan. Teori ini lebih mengedepankan pada urutan pendanaan yang harus dilakukan perusahaan ketika perusahaan mengalami defisit pendanaan internal. Adapun kalangan lain dapat mengkaitkan kebijakan tersebut dengan melihat adanya penambahan dana eksternal akan mengakibatkan kenaikan hutang sehingga jika dikaitkan dengan teori pendekatan tradisional atau teori lainnya maka perubahan hutang akan mengakibatkan adanya perubahan nilai perusahaan.

Sehingga pecking order theory dapat dijadikan landasan yang kuat sekaligus pemicu adanya perubahan struktur permodalan suatu perusahaan yang disebabkan perusahaan tersebut mengalami defisit pendanaan sehingga harus mencari tambahan dana. Sunder dan Myers (1999) mengatakan bahwa adanya hubungan defisit pendanaan internal dengan perubahan struktur permodalan. Ni dan Yu (2008) serta Frank dan Goyal (2003) mengatakan bahwa komponen dari aktifitas terjadinya defisit pendanaan internal dapat dijadikan sebagai faktor- faktor yang mempengaruhi perubahan modal yaitu:

1. Adanya aktivitas pembayaran dividen (dividend payments)

2. Penambahan modal kerja (working capital)

3. Investasi (investment)

4. Aliran kas bersih (net cash flow) 
Website : http://ekomaks.unmermadiun.ac.id/index.php/ekomaks

\section{Penelitian Terdahulu}

Penelitian sebelumnya berupaya menjabarkan 4 variabel pembentuk defisit pendanaan internal dan melihat hubungan dengan perubahan struktur modal dalam perusahaan yang diteliti. Di Indonesia, sangat sedikit penelitian yang memfokuskan pada defisit pendanaan internal terhadap perubahan rasio hutang. Radjiman dan Sudana (2014) memberikan gambaran bahwa di Indonesia pada perusahaan sektor manufaktur lebih banyak menggunakan hutang daripada modal sendiri dan hal ini berbeda jika dibandingkan dengan perusahaan sektor manufaktur di Australia yang lebih menggunakan modal sendiri sehingga di Australia untuk sektor perusahaan manufaktur tidak mendukung Pecking Order Theory.

Penelitian yang dilakukan Apriani (2008) menyimpulkan bahwa dengan melakukan pengujian model pecking order theory dan target adjustment trade-off secara bersama-sama memiliki kemampuan dalam menjelaskan struktur modal, namun secara parsial variabel DEF tidak berpengaruh pada perusahaan manufaktur tahun 2005-2007. Ruslim (2009) memberikan bukti pendukung bahwa defisit pendanaan internal berpengaruh positif terhadap struktur modal perusahaan, studi empiris menunjukkan adanya hubungan positif antara defisit pendanaan internal dengan leverage pada perusahaan emiten non keuangan LQ-45 pada tahun 2000-2006. Primasari (2009) menyimpulkan bahwa dividen memiliki pengaruh secara signifikan positif terhadap perubahan rasio total hutang sedangkan penambahan modal kerja dan investasi tidak memiliki pengaruh secara signifikan. Marseila (2010) menguji defisit pendanaan internal dan didapat hasil berupa adanya pengaruh signifikan antara penambahan modal dan investasi terhadap penerbitan utang baru. Pratiwi (2011) memberikan bukti pendukung bahwa penambahan modal, investasi dan pembayaran dividen memiliki pengaruh yang signifikan terhadap penerbitan utang baru.

Mahardhika (2013) dapat diketahui bahwa dalam pandangan pecking order theory variabel defisit pendanaan berpengaruh terhadap perubahan hutang jangka panjang. Nugraha dan Nugroho (2013) memberikan tambahan bukti empiris bahwa adanya pengaruh secara positif antara defisit pendanaan perusahaan terhadap perubahan hutang jangka panjang pada sampel perusahaan non keuangan di Indonesia yang terdaftar di BEI pada tahun 2006 sampai dengan tahun 2010. Suhendah dan Haryanto (2013) memberikan tambahan dukungan bahwa defisit pendanaan internal pada perusahaan property dan real estate memiliki pengaruh signifikan terhadap perubahan struktur modal. Monica dan Pramesti (2017) memberikan penjelasan bahwa perusahaan non keuangan di indonesia lebih memilih menerbitkan saham atau ekuitas terlebih dahulu ketika mengalami defisit pendanaan internal. Hal tersebut sejalan dengan penelitian Seifert dan Gonenc dalam Monica dan Pramesti (2017) bahwa di negara berkembang memiliki kebiasaan untuk mengisi kekurangan dana dengan menerbitkan ekuitas.

Febriana dan Yulianto (2017) menguji defisit pendanaan internal pada perusahaan manufaktur periode tahun 2011-2015 dan didapat hasil berupa adanya hubungan positif yang terjadi antara defisit pendanaan terhadap penerbitan utang.

\section{Pengembangan Hipotesis dan Kerangka Pemikiran}

\section{Model Pecking Order Theory}

Model pecking order theory dalam penelitian ini didasarkan pada penelitian Sunder dan Myers (1999), Frank dan Goyal (2003) serta Ni dan Yu (2008) yang menjelaskan bahwa diperusahaan yang mengalami defisit pendanaan internal akan melakukan penambahan hutang untuk mencukupi defisit pendanaan yang dialami. Sehingga hipotesis yang dapat dibangun secara umum adalah adanya hubungan positif antara defisit pendanaan internal terhadap penambahan rasio hutang yang dalam hal ini mewakili perubahan struktur modal.

2. Model Extended Pecking Order

Defisit pendanaan internal dapat diteliti lebih jauh dengan melihat faktor pembentuk terjadinya defisit pendanaan internal. Frank dan Goyal (2003) serta Ni dan Yu (2008) menjelaskan bahwa defisit pendanaan internal merupakan penjumlahan dari aktivitas pembayaran dividen, penambahan modal kerja, investasi, dan aliran kas bersih. Aktivitas aktvitas tersebut menyebabkan perusahaan mengalami defisit pendanaan internal sehingga pada akhirnya harus menambah hutang untuk mencukupi pendanaan tersebut. Oleh karena itu maka dapat dibuat hipotesis bahwa pembayaran dividen, penambahan modal kerja, dan investasi berpengaruh secara positif terhadap penambahan hutang. Ketiga aktivitas tersebut menyebabkan perusahaan harus mengeluarkan dana untuk membayar atas kegiatan pembayaran dividen, penambahan modal kerja, dan investasi. Sedangkan untuk aliran kas bersih berpengaruh secara negative terhadap penambahan hutang sehingga semakin besar aliran kas yang didapat maka semakin kecil kemungkinan hutang akan bertambah.

Adapun kerangka pemikiran untuk memperjelas dari hipotesis yang dibangun adalah sebagai berikut: 
Gambar 2.1. Kerangka Pemikiran

\begin{tabular}{|c|c|c|}
\hline Defisit Pendanaan Internal & positif \\
\hline Pembayaran Dividen & positif \\
Penambahan Modal Kerja & positif \\
Investasi & $\begin{array}{c}\text { Penambahan } \\
\text { Rasio Hutang }\end{array}$ \\
\hline Aliran Kas Bersih & negatif \\
\hline
\end{tabular}

\section{IV.METODE PENELITIAN}

\section{A. Data Penelitian}

Data dalam penelitian ini menggunakan data dari laporan keuangan perusahaan yang terdaftar di Bursa Efek Indonesia dengan mengambil subsector Property, Real Estate dan Konstruksi dengan mengambil waktu periode 3 tahun yaitu pada laporan akhir per 31 desember 2015, 2016 dan 2017. Sampel dipilih dengan cara purposive yaitu memilih perusahaan dengan kriteria sebagai berikut:

1. Perusahaan harus terdaftar di Bursa Efek Indonesia dan termasuk dalam subsektor property, real estate dan konstruksi

2. Memiliki laporan keuangan per 31 desember

3. Perusahaan yang dipilih adalah yang memiliki penambahan rasio utang serta memiliki defisit pendanaan internal

4. Perusahaan yang dipilih adalah yang terdapat pembayaran dividen

\section{B. Perumusan Model}

Perumusan model didapat dari penelitian yang telah dilakukan oleh Sunder dan Myers (1999), Frank dan Goyal (2003) serta $\mathrm{Ni}$ dan $\mathrm{Yu}$ (2008) dengan melihat pengaruh defisit pendanaan internal terhadap penambahan rasio hutang maka persamaan pertama adalah:

$$
\Delta D=\alpha+\beta D E F+\epsilon
$$

Dimana:

$\Delta \mathrm{D} \quad$ : Penambahan Rasio Hutang atau Debt Ratio

DEF : Defisit Pendanaan Internal

Dari persamaan pertama diatas maka defisit pendanaan internal dapat dijabarkan lebih lanjut sebagai berikut:

$$
\begin{aligned}
& D E F=D I V+\Delta W C+\Delta I N V+C F O \\
& \Delta D=\alpha+\beta_{1} D I V+\beta_{2} \Delta W C+\beta_{3} \Delta I N V+\beta_{4} C F O+\epsilon
\end{aligned}
$$

Dimana:

$\Delta \mathrm{D} \quad$ : Penambahan Rasio Hutang atau Debt Ratio

DIV : Pembayaran Dividen

$\Delta \mathrm{WC}$ : Penambahan Modal Kerja atau Perubahan Working Capital

$\triangle \mathrm{INV}$ : Investasi atau Perubahan Investasi

CFO : Aliran Kas Bersih atau Net Cash Flow from Operating

\section{Definisi Operasional Variabel}

\section{Penambahan Rasio Hutang ( $\triangle D)$}

Variabel dependen dalam penelitian ini adalah penambahan rasio hutang atau debt ratio yang perubahannya dapat mencerminkan perubahan struktur modal. Penambahan rasio hutang dapat didefinisikan sebagai perubahan debt ratio dari tahun $\mathrm{t}_{-0}{\mathrm{ke} \mathrm{t}{ }_{-}}_{1}$ sehingga dapat dirumuskan sebagai berikut:

$$
\Delta D=\text { Debt Ratio }{ }_{t}-\text { Debt Ratio }_{t-1}
$$


Website : http://ekomaks.unmermadiun.ac.id/index.php/ekomaks

\section{2. $\quad$ Defisit Pendanaan Internal (DEF)}

Defisit pendanaan internal merupakan penjumlahan dari aktivitas pembayaran dividen, penambahan modal kerja, investasi, dan aliran kas bersih. Sesuai penelitian Sunder dan Myer (1999) maka defisit pendanaan internal dapat dirumuskan sebagai berikut:

$$
D E F=D I V+\triangle W C+\triangle I N V+C F O
$$

Dimana:

$\begin{array}{lll}\text { DEF } & : & \text { Defisit Pendanaan Internal } \\ \text { DIV } & : & \text { Pembayaran Dividen } \\ \Delta \mathrm{WC} & : & \text { Penambahan Modal Kerja atau Perubahan Working Capital } \\ \Delta \mathrm{INV} & : & \text { Investasi atau Perubahan Investasi } \\ \mathrm{CFO} & : & \text { Aliran Kas Bersih atau Net Cash Flow from Operating }\end{array}$

3. Pembayaran Dividen (DIV)

Pembayaran dividen merupakan pembayaran aliran kas dari hasil operasional perusahaan kepada pemegang saham. Hasil dari aliran kas tersebut biasanya sudah dikeluarkan dari laba ditahan yang memang didistribusikan kepada pemegang saham (Brigham dan Houston, 2010: 496). Sehingga pembayaran dividen dapat dirumuskan sebagai berikut:

Dividends = Net Income - Retained Earning Required

Pembayaran dividen tidak memerlukan perhitungan karena setiap perusahaan yang terdaftar di Bursa Efek Indonesia memberikan informasi kepada investor mengenai besaran nominal jumlah dividen yang dibayar kepada pemegang saham. Untuk medapatkan nilai berupa skala rasio maka dividen dalam bentuk rupiah dapat dibagi dengan total aset.

4. Penambahan Modal Kerja $(\Delta W C)$

Modal kerja bersih atau sering disebut Net Working Capital merupakan istilah lain dari aset lancar atau aset yang memiliki sifat pengembalian kurang dari 1 tahun (Brigham dan Houston, 2010; 33). Dari definisi diatas maka penambahan modal kerja dapat diartikan bahwa telah terjadinya penambahan aset lancar dari periode sebelumnya dan dapat dirumuskan sebagai berikut:

$$
\Delta \text { Working Capital }=\Delta \text { Current Asset }=\text { Current } \text { Asset }_{t}-\text { Current }_{\text {Asset }} \text { Cu-1 }_{\mathrm{t}}
$$

Untuk medapatkan nilai berupa skala rasio maka perubahan working capital dalam bentuk rupiah dapat dibagi dengan total aset.

5. Investasi $(\triangle I N V)$

Brealey, Myers dan Marcus $(2007 ; 4)$ menjelaskan bahwa investasi pada umumnya dikaitkan dengan capital investment atau investasi yang dilakukan untuk menambah aset tetap. Dari pengertian tersebut maka investasi merupakan penambahan aset tetap. Adapun rumusnya adalah sebagai berikut:

$$
\Delta \text { Investasi }=\Delta \text { Fix Asset }=\text { Fix Asset } \text { t }_{\mathrm{t}}-\text { Fix Asset }_{\mathrm{t}-1}
$$

Untuk medapatkan nilai berupa skala rasio maka penambahan investasi dalam bentuk rupiah dapat dibagi dengan total aset

6. Aliran Kas Bersih (CFO)

Aliran kas bersih dapat dibagi menjadi 3 jenis yaitu aliran kas bersih dari kegiatan operasional, kegiatan investasi dan kegiatan pendanaan. Aliran kas bersih dapat dihitung dari hasil EBIT dikurangi pajak ditambah depresiasi serta dikurangi dari perubahan working capital dan perubahan capital expenditure (Brealey, Myers dan Marcus, 2012; 65). Dalam penelitian ini aliran kas bersih menggunakan aliran kas bersih dari kegiatan operasional dapat dicari dari EBIT dikurangi taxes dan ditambah depresiasi (Brealey, Myers dan Marcus, 2012; 65). Atau dengan kata lain aliran kas bersih dari kegiatan operasional didapat dari Earning After Tax ditambah depresiasi (Ruslim, 2009). Sehingga dapat dirumuskan sebagai berikut:

Aliran Kas Bersih dari Kegiatan Operasional = EAT + Depreciation and Amortization

\section{Metode Analisis}

Defisit pendanaan internal yang menjadi faktor utama adanya penambahan rasio hutang akan dilihat hubungannya dengan menggunakan metode analisis regresi linier. Analisis regresi linier tunggal digunakan untuk melihat hubungan antara defisit pendanaan internah terhadap penambahan atau perubahan rasio hutang, sedangkan analisis regresi linier berganda digunakan 
Website : http://ekomaks.unmermadiun.ac.id/index.php/ekomaks

untuk melihat hubungan secara parsial yaitu pembayaran dividen, penambahan modal kerja, investasi, dan aliran kas bersih terhadap perubahan atau penambahan rasio hutang.

Uji asumsi klasik digunakan untuk melihat kualitas persamaan regresi yang didapat dan selanjutnya akan dilakukan uji- $\mathrm{t}$ untuk melihat hubungan secara parsial antar variabel sedangkan untuk mempermudah analisis regresi linier tunggal dan berganda maka digunakan alat bantu SPSS.

\begin{tabular}{cccc}
\multicolumn{4}{c}{ Tabel 4.1. Hasil Uji Regresi Berganda } \\
\hline Model & $\begin{array}{c}\text { Standardized } \\
\text { Coefficients } \\
\text { Beta }\end{array}$ & T & Sig. \\
& & & \\
\hline (Constant) & .056 & 2.178 & .032 \\
DEF & -.659 & -2.504 & .014 \\
DIV & .097 & .022 \\
WC & .097 & .035 \\
INV & -.214 & .001 \\
CFO & .056 & \\
R Square Model 1 & .044 & \\
Adjusted R Square Model 1 & 4.746 & \\
F hitung Model 1 & .032 & \\
Sig. Model 1 & .287 & \\
R Square Model 2 & .250 & \\
Adjusted R Square Model 2 & 7.761 & \\
F hitung Model 2 & .000 & \\
Sig. Model 2 & Sumber : Hasil pengolahan data SPSS Versi 16
\end{tabular}

\section{Koefisien Determinasi}

Berdasarkan tabel 4.8 menunjukkan nilai R Square model 1 sebesar 0,056. Hal tersebut menunjukkan bahwa variabel independen Defisit Pendanaan Internal berpengaruh sebesar 5,6\% terhadap variabel independen dan sisanya dipengaruhi oleh variabel lain diluar model penelitian. Sedangkan nilai R Square model 2 sebesar 0,287 . Hal tersebut menunjukkan bahwa variabel independen DIV, WC, INV, dan CFO berpengaruh sebesar 28,7\% terhadap variabel independen dan sisanya $71,3 \%$ dipengaruhi oleh variabel lain diluar model penelitian.

2. $\quad$ Uji Signifikansi Simultan ( Uji Statistik F)

Berdasarkan hasil uji F pada tabel 4.8 nilai F hitung Model 1 sebesar 4,746 dengan sigifikansi 0,032. Karena sigifikansi lebih kecil dari 0,05 artinya terdapat pengaruh variabel Defisit Pendanaan Internal terhadap Debt Ratio. Sedangkan nilai F hitung Model 2 sebesar 7,761 dengan sigifikansi 0,000. Karena sigifikansi lebih kecil dari 0,05 artinya terdapat pengaruh variabel DIV, WC, INV, dan CFO terhadap Debt Ratio pada perusahaan sub sektor property, real estate, dan konstruksi yang terdaftar di Bursa Efek Indonesia (BEI) selama periode 2015, 2016, dan 2017.

3. Uji Signifikansi Induvidual

a) Pengaruh Defisit Pendanaan Internal terhadap Perubahan Struktur Keuangan

Hasil penelitian ini menunjukkan bahwa variabel Defisit Pendanaan Internal $\left(\mathrm{X}_{1}\right)$ mempunyai nilai signifikan sebesar 0,032. Nilai ini lebih kecil dari $0,05(0,032<0,05)$. Sehingga dapat dijelaskan bahwa variabel Defisit Pendanaan Internal $\left(\mathrm{X}_{1}\right)$ secara parsial mempunyai pengaruh signifikan terhadap Perubahan Struktur Keuangan.

b) Pengaruh Pembayaran Deviden terhadap Perubahan Struktur Keuangan

Hasil penelitian ini menunjukkan bahwa variabel Pembayaran Deviden $\left(\mathrm{X}_{2}\right)$ mempunyai nilai signifikan sebesar 0,014. Nilai ini lebih kecil dari 0,05 $(0,014<0,05)$. Sehingga dapat dijelaskan bahwa variabel Pembayaran Deviden $\left(\mathrm{X}_{2}\right)$ secara parsial mempunyai pengaruh signifikan terhadap Perubahan Struktur Keuangan.

c) Pengaruh Penambahan Modal Kerja terhadap Perubahan Struktur Keuangan

Hasil penelitian ini menunjukkan bahwa variabel Penambahan Modal Kerja $\left(\mathrm{X}_{3}\right)$ mempunyai nilai signifikan sebesar 0,022. Nilai ini lebih kecil dari $0,05(0,022<0,05)$. Sehingga dapat dijelaskan bahwa variabel Penambahan Modal Kerja $\left(\mathrm{X}_{3}\right)$ secara parsial mempunyai pengaruh signifikan terhadap Perubahan Struktur Keuangan.

d) Pengaruh Investasi terhadap Perubahan Struktur Keuangan

Hasil penelitian ini menunjukkan bahwa variabel Investasi $\left(X_{4}\right)$ mempunyai nilai signifikan sebesar 0,035 . Nilai ini lebih kecil dari $0,05(0,035<0,05)$. Sehingga dapat dijelaskan bahwa variabel Investasi $\left(\mathrm{X}_{4}\right)$ secara parsial mempunyai pengaruh signifikan terhadap Perubahan Struktur Keuangan. 
Website : http://ekomaks.unmermadiun.ac.id/index.php/ekomaks

e) Pengaruh Aliran Kas Masuk terhadap Perubahan Struktur Keuangan

Hasil penelitian ini menunjukkan bahwa variabel Aliran Kas Masuk $\left(\mathrm{X}_{5}\right)$ mempunyai nilai signifikan sebesar 0,001. Nilai ini lebih kecil dari $0,05(0,001<0,05)$. Sehingga dapat dijelaskan bahwa Aliran Kas Masuk $\left(\mathrm{X}_{5}\right)$ secara parsial mempunyai pengaruh signifikan terhadap Perubahan Struktur Keuangan.

\section{Temuan}

Pengujian yang telah dilakukan dapat disimpulkan bahwa adanya pengaruh yang signifikan Defisit Pendanaan Internal (DEF), Pembayaran Deviden (DIV), Penambahan Modal Kerja (WC), Investasi (INV), dan Aliran Kas Masuk (CFO) terhadap Struktur Keuangan pada perusahaan sub sektor property, real estate, dan konstruksi yang terdaftar di Bursa Efek Indonesia (BEI) selama periode 2015, 2016, dan 2017.

Dan pengujian secara simultan menunjukkan hasil yang berpengaruh terhadap Struktur Keuangan pada perusahaan sub sektor property, real estate, dan konstruksi yang terdaftar di Bursa Efek Indonesia (BEI) selama periode 2015, 2016 , dan 2017.

\section{KESIMPULAN}

Penelitian ini dibuat untuk melihat konsistensi pecking order theory dalam perusahaan-perusahaan sub sektor property, real estate, dan konstruksi yang terdaftar di Bursa Efek Indonesia (BEI) selama periode 2015, 2016, dan 2017. Berlatar belakang masih adanya research gap dari variabel - variabel pembentuk defisit pendanaan internal maka dilakukan penelitian dari 33 perusahaan yang telah dipilih berdasarkan kriteria yang ada.

\section{VI.DAFTAR PUSTAKA}

Apriani, Tiar. 2008. Analisis Kebijakan Struktur Modal, Pengujian Pecking Order Theory dan Trade off Theory. Skripsi Jurusan Manajemen Fakultas Ekonomika dan Ilmu Sosial Universitas Islam Negeri Syarif Hidayatullah.

Brealey, Richard A., Myers, Stewart C and Marcus, Alan J. 2012. Fundamentals of Corporate Finance. $7^{\text {th }}$ Edition. New York: McGraw-Hill Companies Inc. Brigham, Eugene F and Houston, Joel F. 2010. Essentials of Financial Management. Second Edition. Singapore: Cengage Learning Asia Pte Ltd.

Febriana, D. dan Yulianto, A. 2017. Pengujian Pecking Order Theory di Indonesia. Management Analysis Journal 6 (2) Universitas Negeri Semarang

Frank, Murray Z and Goyal, Vidhan K, 2003. Testing The Pecking Order Theory of Capital Structure. Journal of Financial Economics, Vol.67, pp.217-248.

Hanafi, Mamduh M. 2012. Manajemen Keuangan. Edisi Pertama. Yogyakarta: BPFE.

Jogiyanto, H., M. 2010. “Metode Penelitian Bisnis: Salah Kaprah dan Pengalaman-Pengalaman”. Edisi Pertama. Yogyakarta: BPFE.

Kuncoro, M. 2010. Metode Kuantitatif: Teori dan Aplikasi untuk Bisnis dan Ekonomi. Edisi 4. Yogyakarta: UPP STIM YKPN.

Mahardhika, Bhagas. 2013. Pengujian Pecking Order Theory dan Trade off Theory pada Struktur Modal Perusahaan (Studi pada Perusahaan Consumer Goods di Bursa Efek Indonesia). Jurnal ekonomi dan bisnis Universitas Brawijaya Malang.

Marseila, Livanna. 2010. Pengujian Pecking Order Theory versus Static Trade -Off Theory dalam Keputusan Struktur Modal pada Perusahaan di Bursa Efek Indonesia. Skripsi (tidak dipublikasikan) Jurusan Manajemen Fakultas Ekonomika dan Bisnis Universitas Gadjah Mada Yogyakarta.

Monica, Joedith dan Pramesti, Muthia. Pengujian Pecking Order Theory Terhadap Perusahaan Surplus Non Keuangan di Bursa Efek Indonesia. Jurnal Manajemen Teknologi. Vol 16 (2) 2017.

$\mathrm{Ni}$, Jinlan and Yu, Miaomiao. 2008. Testing The Pecking Order Theory. The Chinese Economy, Vol.41, No-1, pp.97-113.

Pratiwi, Permata Dian. 2011. Struktur Modal Perusahaan - Perusahaan Terbuka Sektor Non Keuangan di Pasar Modal Indonesia. Skripsi (tidak dipublikasikan) Jurusan Manajemen Fakultas Ekonomika dan Bisnis Universitas Gadjah Mada Yogyakarta.

Primasari, Kirana Dewi. 2009. Pengujian Pecking Order Pada Perusahaan Non Keuangan LQ45 Periode 2004-2008. Skripsi (tidak dipublikasikan) Jurusan Manajemen Fakultas Ekonomika dan Bisnis Universitas Gadjah Mada Yogyakarta.

Radjamin, Iryuvita Januarizka Putri dan Sudana, I Made. Penerapan Pecking Order Theory Dan Kaitannya Dengan Pemilihan Struktur Modal Perusahaan Pada Sektor Manufaktur di Negara Indonesia dan Negara Australia. Jurnal Manajemen Bisnis Indonesia. Vol.1 No 3 Juni 2014.

Ruslim, Herman. 2009. Pengujian Struktur Modal (Teori Pecking Order): Analisis Empiris Terhadap Saham di LQ-45. Jurnal Bisnis dan Akuntansi, Vol.11, No.3, Hlm. 209-221.

Sartono, R. Agus. 2010. Manajemen Keuangan: Teori dan Aplikasi. Edisi 4. Yogyakarta: BPFE.

Suhendah, Rousilita dan Haryanto, Melinda. (2013. Investigasi Model Pecking Order Thepry dan Static Order Trade Off Pada Perusahaan Property dan Real Estate. Prosiding Simposium Nasional Akuntansi Vokasi Ke -2. Mei 2013

Sumodiningrat, G. 2012. Ekonometrika Pengantar’. Yogyakarta: ANDI.

Sunder, Lakshmi Syam and Myers, Stewart C. 1999. Testing Static Tradeoff Against Pecking Order Models of Capitals Structure. Journal of Financial Economics, 51, pp. 219-224.

Utami, Novia. 2018. Analisis Faktor-Faktor yang Mempengaruhi Struktur Modal Perusahaan Consumer Goods di Bursa Efek Indonesia Periode 2013-2017 Pengujian Pecking Order Theory. Jurnal Fakultas Ekonomi dan Bisnis Universitas Katolik Indonesia Atma Jaya

Weston, J. Fred dan Copeland, Thomas E. 2010. Manajemen Keuangan. Edisi Revisi Jilid 2. Bandung: Binarupa Aksara Publisher.

Ghozali, Imam. 2018. Aplikasi Analisis Multivariate dengan Program SPSS. Badan Penerbit Universitas Diponegoro, Semarang. 